Situs Jurnal : $\underline{\text { http://ejournal.stiepancasetia.ac.id/index.php/iieb }}$

Jilid 6 Nomor 1 Maret 2020

Hal 12 - 25

\title{
PENGEMBANGAN PRODUK EKONOMI KREATIF KAIN SASIRANGAN DAN PENERAPAN STRATEGI KOMUNIKASI PEMASARAN TERPADU DALAM MENINGKATKAN DAYA TARIK KOTA BANJARMASIN SEBAGAI DESTINASI PARIWISATA
}

\section{Kasypul Anwar, Gt. Irhamni}

Abstrak: Tujuan dalam penelitian yakni Untuk mengetahui, mengkaji dan menganalisis seberapa besar pengaruh pengambangan produk ekonomi kreatif kain sasirangan dan penerapan strategi komunikasi pemasaran terpadu terhadap daya tarik Kota Banjarmasin sebagai destinasi pariwisata. Penelitian ini menggunakan metode explanatory survey, karena akan menjelaskan hubungan antara variabel yang diteliti. Sedangkan tipe hubungan antara variabel yang digunakan dalam penelitian ini adalah kausalitas yaitu variabel bebas mempengaruhi variabel terikat. hasil penelitian menunjukkan bahwa secara umum strategi komunikasi pemasaran terpadu pada produk ekonomi kreatif di Kota Bajarmasin telah dilaksanakan dengan baik. Hal ini terlihat dari maroritas jawaban responden yang menyatakan setuju dengan pertanyaan yang diajukan. Namun dari keempat faktor pembentuk komunikasi pemasaran terpadu, aspek hubungan masyarakat dan publisitas serta periklanan merupakan faktor pembentuk yang memiliki peranan paling kuat dan telah dilaksanakan dengan cukup baik. Artinya secara keseluruhan pihak pengelola pariwisata maupun industri pariwisata ekonomi kreatif telah melakukan serangkaian promosi untuk memperkenalkan apa yang dimiliki kepaca seluruh calon wisatawan melalui berbagai media.

Kata Kunci: Produk, Strategi, Pemasaran, Daya Saing.

\section{Latar Belakang}

Kreatifitas merupakan modal utama dalam menghadapi tantangan global. Bentuk-bentuk ekonomi kreatif selalu tampil dengan nilai tambah yang khas, menciptakan pasarnya sendiri, dan berhasil menyerap tenaga kerja serta pendapatan ekonomis. Untuk mengembangkan ekonomi kreatif, diperlukan sejumlah SDM yang berkualitas dengan daya inovatif dan kreativitas yang tinggi. Namun, di samping kebutuhan akan SDM yang berkualitas, pengembangan ekonomi kreatif juga membutuhkan ruang atau wadah sebagai tempat penggalian ide, berkarya, sekaligus aktualisasi diri dan ide-ide kratif. Di negara-negara maju, pembentukan ruang-ruang kreatif tersebut telah mengarah pada kota kreatif (creative city) yang berbasis pada penciptaan suasana yang kondusif bagi komunitas sehingga dapat mengakomodasi kreativitas. Kota-kota di Indonesia, dengan sejumlah keunikannya, memiliki potensi untuk dikembangkan sebagai kota-kota kreatif.

Pengembangan ekonomi kreatif dapat dilakukan seiring dengan pengembangan wisata. Kota-kota wisata di Indonesia, seperti Kota Banjarmasin sebenarnya telah memiliki ruang kreatif, yaitu zona-zona wisata itu sendiri. Atraksi 
wisata dapat menjadi sumber ide-ide keatif yang tidak akan pernah habis untuk dikembangkan. Proses kreativitas seperti pembuatan souvenir dan industri kuliner dapat menjadi atraksi wisata tersendiri yang memberikan nilai tambah. Sementara di sisi lain, pasar yang menyerap produk ekonomi kreatif telah tersedia, yaitu melalui turis atau wisatawan yang berkunjunng ke obyek wisata.

Salah satu alasan dari pengembangan industri kreatif adalah adanya dampak positif yang akan berpengaruh pada kehidupan sosial, iklim bisnis, peningkatan ekonomi, dan juga berdampak para citra suatu kawasan tersebut. Dalam konteks pengembangan ekonomi kreatif pada kota-kota di Indonesia, industri kreatif lebih berpotensi untuk berkembang pada kota-kota besar atau kota-kota yang telah dikenal. Hal ini terkait dengan ketersediaan sumber daya manusia yang handal dan juga tersedianya jaringan pemasaran yang lebih baik dibanding kota-kota kecil.

Kota Banjarmasin adalah sebuah kota di Kalimantan Selatan. Industri ekonomi kreatif di kota ini berkembang dengan pesat seiring dengan adanya kebijakan-kebijakan pemerintah yang mendukung pengembangan ekonomi kreatif. Bahkan dalam perjalannya konsep industri kreatif yang digagas Kota Banjarmasin, akan dijadikan sebagai model percontohan oleh oleh daerah lainnya di Provinsi Kalimantan Selatan, agar daerah lain bisa melakukan hal yang sama. Saat ini industri kreatif yang ada di Kota Banjarmasin bisa dibilang paling maju dibandingkan daerah lainnya.

Perkembangan industri ekonomi kreatif yang positif di Kota Banjarmasin baik langsung maupun tidak langsung berimplikasi pada peningkatan daya tarik wisatawan terhadap tujuan wisata yang ada di Kota Banjarmasin. Diantara sekian banyak industri kreatif yang ada di Kota Banjarmasin, produk yang terus berkembang diantaranya adalam kuliner, batik dan kerajinan serat alam. Kuliner, batik dan kerajinan serat alam di Kota Banjarmasin merupakan salah satu produk yang mengalami kemajuan pesat dengan pangsa pasar yang luas. Seperti misalnya kerajinan, konveksi, kuliner, desain grafis, aksesori, hingga bisnis start up.

Usaha-usaha tersebut digolongkan kreatif lantaran dipasarkan atau dipromosikan dengan cara yang tidak biasa. Dengan kata lain, tidak sekadar jualan. Tapi, ada strategi khusus dalam bidang pemasaran dan promosinya. Selain itu, juga ada nilai tambah yang bertujuan mengkampanyekan kepada konsumen agar mencintai dan menghargai produk lokal, sehingga ada kebanggaan.

Sedangkan untuk produk Kain Sasirangan saat ini terus berkembang dengan berbagai model dan motif, hingga saat ini terdapat berbagai macam motif batik yang ditawarkan Kota Banjarmasin. Corak khas pada kain sasirangan diperoleh dari teknik-teknik khusus yang dipengaruhi oleh beberapa hal yakni, teknik jahitan serta ikatan, komposisi warna, dan jenis bahan pengikat/jenis benang. Dari hal-hal tersebutlah corak serta motif khas sasirangan terbentuk. Motif pada kain sasirangan pada umumnya dapat digolongkan menjadi 3 kelompok yakni:

1. Motif lajur, yakni bentuk motif yang dirangkai secara memanjang. Contoh: hiris pudak, kulat karikit, gigi haruan, kangkung kaumbakan.

2. Motif ceplok, yaitu bentuk motif yang tampil secara sendiri tanpa ada motif lain yang mendampingi. Contoh: tampuk manggis, hiris gagatas, atau tampuk manggis. 
3. Motif variasi, yaitu motif penghias sebagai tambahan dalam motif dalam lain yang sudah ada. Contoh: motif hiris gagatas yang diberi pinggiran agar terlihat lebih menarik.

Daya tarik wisata memiliki peranan penting yang dapat dijadikan sebagai daya tarik bagi seseorang atau calon wisatawan untuk berkunjung ke suatu daerah tujuan wisata. Daya tarik yang tidak atau belum dikembangankan merupakan sumber daya potensial dan belum dapat disebut daya tarik wisata, sampai adanya suatu jenis pengembangan tertentu. Objek dan daya tarik wisata merupakan dasar bagi kepariwisataan. Tanpa adanya daya tarik di suatu daerah atau tempat tertentu kepariwisataan sulit untuk dikembangkan.

\section{Kajian Literatur}

Konsep pemasaran merupakan falsafah perusahaan yang menyatakan bahwa keinginan pembeli adalah syarat utama bagi kelansungan hidup perusahaan. Perusahaan yang menganut konsep pemasaran ini tidak hanya menjual barang ataupun jasa saja, tetapi lebih dari pada itu. Dimana perusahaan harus memperhatikan konsumen dan memenuhi kebutuhannya dengan cara yang menguntungkan sehingga memuaskan konsumen (Kotler, 2004:76). Pemasaran adalah analisis, perencanaan, implementasi, dan pengendalian dari programprogram yang dirancang untuk menciptakan, membangun, dan memelihara pertukaran yang menguntungkan dengan pembeli sasaran untuk mencapai tujuan perusahaan.

Sedangkan Rusmini (2013:32) menjelaskan bahwa pemasaran adalah untuk membina hubungan jangka panjang yang memuaskan dengan pihak-pihak pelanggan, pemasok dan penyalur sehingga dapat mempertahankan preferensi dan bisnis jangka panjang. Jaringan pemasaran terdiri atas pihak-pihak yang berkepentingan dan mendukung kebersamaan dengan perusahaan sehingga dapat membangun bisnis yang saling menguntungkan.

Untuk menghasilkan tanggapan, yang dinginkan dalam pasar sasaran dengan memilih kombinasi yang tepat dengan unsur-unsur yang terdapat dalam bauran pemasaran yang dikenal dengan 4P yaitu Product, Price, Place dan Promotion. Perusahaan dapat memilih dari sekian banyak variabel untuk satu kombinasi, sesuai dengan lingkungannya (Kotler, 2004:105):

1. Produk

Atribut sebuah produk seperti mutu, ciri dan desain. Mutu produk menunjukkan kemampuan produk untuk menjalankan fungsinya. Ciri produk merupakan sarana kompetitif perusahaan pesaing sedangkan pesaing dapat mengembangkan kegunaan daan manfaat produk yang mudah, aman, murah sederhana serta bersifat ekonomis dalam produksi daan distribusinya.

2. Harga

Harga adalah satu variabel pemasaran yang perlu diperhatikan oleh manajemen perusahaan, karena harga akan langsung mempengaruhi besarnya volume penjualan dan laba yang dicapai oleh perusahaan, karena harga akan langsung mempengaruhi besarnya volume penjualan dan laba yang dicapai oleh perusahaan. Harga yang ditetapkan harus menutup semua ongkos atau bahkkan lebih dari itu memberikan laba perusahaan mengalami merugikan. 


\section{Distribusi}

Setiap perusahaan perlu memaksanakan fungsi distribusi. Hal ini merupakan faktor yang sangat penting dalam upaya memperlancar arus barang dan jasa sebab kesalahan dalam pemilihan saluraan distribusi dapat mempelancar penyalur barang. Proses permindahan barang atau jasa dari pihak penjual kepada pihak pembeli (konsumen akhir) inilah yang disebut distribusi pemasaran, sedangkan badan-badan atau lembaga-lembaga organisasi atau individu yang terkait di dalaamnya serta sarana yang digunakan untuk proses perpindahan ini sebut saluran distribusi.

4. Promosi

Promosi merupakan (komunikasi pemasaran) yang meliputi semua kegiatan yang dilakukan perusahaan untuk mengkomunikasikan dan mempromosikan produknya kepada pasar sasaran.

Kotler (2001:101) menyebutkan pemasaran sebagai suatu proses social dan manajerial yang membuat individu dan kelompok memperoleh apa yang mereka butuhkan dan inginkan lewat penciptaan dan pertukaran rimbal balik produk dan nilai dengan orang lain. Sementara itu Pawitra (2001: 261-265) menjelaskan pemasaran adalah adanya pertukaran barang dengan barang, barang dengan jasa, atau jasa dengan jasa dari suatu pihak dengan pihak lain, baik yang sifatnya terbatas maupun luas dan kompleks. Pertukaran terbatas hanya terdiri atas dua pihak saja, sedangkan pertukaran yang luas bias melibatkan lebih dari dua pihak, yaitu bukan hanya pihak pembeli dan penjual saja, akan tetapi melibatkan pihak lain yang secara tidak langsung bertemu dengan konsumen. Bogozzi dalam Pawitra (2001:64-65) menggambarkan bahwa proses pertukaran yang kompleks melibatkan beberapa pihak yang tidak secara langsung saling terkait. Pemasaran pariwisata (tourism marketing) adalah suatu sistim dan koordinasi yang dilaksanakan sebagai suatu kebijakan bagi perusahaan-perusahaan yang bergerak di bidang kepariwisataan, baik milik swasta maupun pemerintah dalam rung lingkup lokal, regional, nasional dan internasional untuk dapat mencapai kepuasan wisatawan dengan memperoleh keuntungan yang wajar (Yoety, 2000:30).

Dari uraian di atas dapat disimpulkan bahwa pemasaran pariwisata merupakan keseluruhan aktivitas yang diarahkan untuk memberikan informasi kepada konsumen yang bertujuan untuk memuaskan keinginan wisatawan sebagai konsumen.

Untuk melaksanakan kegiatan ini perlu disusun suatu strategi pemasaran yang diarahkan pada usaha untuk memenuhi kebutuhan dan keinginan wisatawan, khususnya pada target wisata yang akan dilayani.

Faktor yang perlu diperhatikan untuk memenuhi calon wisatawan agar mau memanfaatkan produk pariwisata yang ditawarkan adalah sebagai berikut:

1. Menawarkan produk pariwisata yang bernilai, yaitu memiliki keunggulan kualitas dan pelayanan produknya (produck).

2. Menerapkan harga produk pariwisata yang wajar, dalam arti ada kesamaan manfaat antara penjual dan pembeli (price).

3. Mengupayakan terjalinnya komunikasi dengan calon pembeli melalui usaha promosi untuk meyakinkan akan manfaat dan kualitas produk pariwisata yang ditawarkan kepada target pasar yang dilayani (promotion). 
4. Menciptakan model saluran distribusi penjualan produk pariwisata yang mampu menjamin ketersediaannya dalam berbagai siatusi (distribution).

Pemasaran produk pariwisata beroriantasi pada wisatawan, yaitu dalam penyiapan produk pariwisata yang akan ditawarkan kepada konsumen, senantiasa memperhatikan motivasi dan kepuasan wisatawan.

Untuk memasarkan produk industri pariwisata bukan saja diperlukan koordinasi, tetapi juga diperlukan kerjasama yang baik antara organisasi yang bertanggung jawab dalam pengembangan pariwisata dengan semua pihak yang terlibat dan terkait dengan kegiatan pariwisata.

Pemasaran pariwisata merupakan "suatu proses manajemen yang dilakukan oleh organisasi pariwisata maupun idustri pariwisata untuk melakukan identifikasi terhadap wisatawan yang sudah punya keinginan untuk melakukan perjalanan wisata dan wisatawan yang berpotensi akan melakukan perjalanan wisata dengan jalan melakukan komunikasi dengan mereka, mempengaruhi keinginan, kebutuhan, memotivasinya, terhadap apa yang disukai dan yang tidak disukainya, pada tingkat lokal, regional, nasional ataupun internasional dengan menyediakan objek dan atraksi wisata agar wisatawan memperoleh kepuasan optimal" (Salah Wahab dkk dalam Yoeti; 2002:2).

Dengan demikian pada dasarnya pemasaran pariwisata adalah suatu upaya yang dilakukan baik oleh organisasi parwisata Nasional, organisasi Daerah maupun industri pariwisata untuk menarik wisatawan sebanyak mungkin mengunjungi objek wisata, lebih lama tinggal dan lebih banyak membelanjakan uangnya di daerah tujuan wisata yang dikunjungi tersebut, dengan demikian perencanaan pamasaran produk wisata yang akan ditawarkan kepada wisatawan harus cocok (match) dengan apa yang diinginkan dan diharapkan konsumen (wisatawan) sehingga timbul ketertarikan untuk membeli produk tersebut, maka pengetahuan tentang segmen pasar dan karakteristik wisatawan (sosio-demografi, psykografinya) adalah sangat penting bagi pembuat perencanaan dalam merancang bentuk pemasaran yang tepat sasaran.

Pemasaran pariwisata yang baik harus dapat meningkatkan daya tarik pariwisata yang diwarkan. Menurut Gunawan (2003:47) menyatakan bahwa salah satu strategi pemasaran yang dapat meningkatkan daya tarik pariwisata adalah komunikasi pemasaran terpadu, dimana dengan adanya komunikasi pemasaran yang dikelola secara proporsional dan professional dapat menumbuhkan citra kawasan wisata yang positif di benak wisatawan. Komunikasi pemasaran terpadu harus diterapkan sesuai dengan aspek-aspek yang terkadung didalamnya, sehingga terjalin sinergi yang baik antara promosi yang dilakukan dengan pengelolaan pariwisatanya.

\section{Metode Penelitian}

Penelitian ini menggunakan metode explanatory survey, karena akan menjelaskan hubungan antara variabel yang diteliti. Sedangkan tipe hubungan antara variabel yang digunakan dalam penelitian ini adalah kausalitas yaitu variabel independen/variabel bebas mempengaruhi variabel depeden/variabel terikat (Sugiyono, 2006:39). Penelitian explanatory mengacu pada hipotesis yang akan diuji terhadap fenomena yang terjadi. Penelitian ini berdasarkan cakupan waktu 
bersipat cross sectional yang mencerminkan deskripsi dari suatu keadaan dan fenomena yang terjadi pada waktu saat tertentu (Sekaran, 2003:73).

Mengacu pada tujuan penelitian yang akan dilakukan yaitu untuk mengetahui dan mengkaji lebih dalam terhadap variabel-variabel penelitian yang akan diteliti yaitu maka penelitian ini bersifat deskritif dan verifikatif. Penelitian deskriptif adalah penelitian yang bertujuan untuk memperoleh gambaran atau deskripsi tentang variabel yang diteliti. Sedangkan penelitian verifikatif adalah untuk mengetahui hubungan antar variabel melalui suatu pengujian hipotesis berdasarkan data di lapangan.

\section{Hasil Penelitian dan Pembahasan}

Pengaruh Penerapan Strategi Komunikasi Pemasaran Terpadu Pada Produk Ekonomi kreatif Terhadap Daya Tarik Kota Banjarmasin Sebagai Destinasi Pariwisata

\section{Hasil Uji Asumsi Klasik}

Maksud dilakukakan pengujian asumsi dalam penelitian ini adalah untuk mendapatkan model regresi yang baik dan benar-benar mampu memberikan estimasi yang handal dan tidak bias. Analisis regresi juga menunjukkan arah hubungan antara variabel dependen dengan variabel independen. Teknik estimasi variable dependen yang melandasi independen analisis tersebut disebut Ordinary Least Squares (OLS).

Model regresi yang menggunakan teknik OLS, sering disebut sebagai model regresi linear klasik. Untuk dapat dianalisis hasilnya, model tersebut harus menggunakan asumsi OLS. Terdapat 10 asumsi OLS yang harus dipenuhi, tetapi pada umumnya hanya 4 uji yang harus dilakukan yaitu Uji Normalitas, Uji Heteroskedastisitas, Uji Autokorelasi, dan Uji Multikolinieritas. Pengujian ini dilakukan untuk meyakini bahwa model regresi yang diperoleh mempunyai kemampuan untuk memprediksi, dan kemanfaatan dalam pengambilan keputusan.

\section{a. Uji Multikolinieritas}

Multikolinieritas adalah suatu keadaan di mana salah satu atau lebih variabel independen dapat dinyatakan sebagai kombinasi linier dari variabel independen lainnya. Cara yang digunakan untuk mendeteksi ada tidaknya Multikolinieritas adalah dengan melakukan regresi antar variabel penjelas. Jika signifikan berarti terdapat Multikolinieritas. Untuk menguji Multikolinieritas dengan vasilitas yang disediakan SPSS yaitu dengan melihat nilai VIF dari masing-masing variabel. Jika nilai VIF lebih rendah dari 10, maka dapat disimpulkan bahwa tidak ada Multikolinieritas yang serius antara variabel independen dalam model. Dengan melihat nilai VIF dalam model regresi dapat diketahui bahwa masing-masing variabel tidak mengandung adanya gejala Multikolinieritas karena mempunyai nilai VIF yang lebih rendah dari 10. Hal ini menunjukkan model regresi tersebut lolos uji Multikolinieritas.

\section{Tabel}


Ringkasan Hasil Pengujian Multikolinieritas

Dengan Menggunakan Varian Inflas Factor (VIF)

$\mathrm{N}=96$

\begin{tabular}{|l|l|r|c|}
\hline \multicolumn{2}{|c|}{ Model } & \multicolumn{2}{c|}{ Collinearity Statistics } \\
\cline { 3 - 4 } \multicolumn{2}{|c|}{} & Tolerance & \multicolumn{1}{c|}{ VIF } \\
\hline 1 & (Constant) & & \\
\hline & $\begin{array}{l}\text { Komunikasi.Pemasara } \\
\text { n.Terpadu }\end{array}$ & 1.000 & 1.000 \\
\hline
\end{tabular}

a Dependent Variable: Daya.Tarik.Pariwisata

Sumber: Data Primer Yang Diolah, 2018

Tabel diatas memperlihatkan bahwa hasil perhitungan nilai tolerance menunjukkan tidak ada variabel independen yang memiliki nilai tolerance kurang dari 0,10 yang berarti tidak ada korelasi antar variabel independen yang nilainya lebih dari 95\%. Hasil perhitungan Variance Inflation Factor (VIF) juga menunjukkan hal yang sama, tidak ada satu variabel independen yang memiliki nilai VIF lebih dari 10. Jadi dapat disimpulkan bahwa tidak ada Multikolonieritas antar variabel independen dalam model regresi.

\section{b. Uji Autokorelasi}

Uji autokerelasi yang digunakan dalam penelitian ini adalah Uji Durbin-Watson (DW Test). Uji Durbin Watson hanya digunakan untuk autokorelasi tingkat satu (first order autocorrelation) dan mensyaratkan adanya intercept (konstanta) dalam model regresi dan tidak ada variabel lagi di antara variabel indepeden. Selanjutnya uji autokerelasi Durbin-Watson (DW Test) dilakukan dengan menggunakan bantuan Program SPSS ver 15 for windows, hasil olah data terlihat seperti Tabel 4.16. berikut:

Tabel

Hasil Uji Autokorelasi dengan Durbin-Watson (DW Test)

\begin{tabular}{|c|c|c|c|c|c|}
\hline \multicolumn{6}{|c|}{$N=96$} \\
\hline Model & $\mathrm{R}$ & R Square & $\begin{array}{l}\text { Adjusted } \\
\text { R Square }\end{array}$ & $\begin{array}{l}\text { Std. Error } \\
\text { of the } \\
\text { Estimate }\end{array}$ & $\begin{array}{l}\text { Durbin- } \\
\text { Watson }\end{array}$ \\
\hline 1 & $.649(a)$ & .421 & .401 & 5.08722 & 1.975 \\
\hline
\end{tabular}

a Predictors: (Constant), Komunikasi.Pemasaran.Terpadu

b Dependent Variable: Daya.Tarik.Pariwisata

Sumber: Data Primer Yang Diolah

Tabel diatas memperlihatkan bahwa nilai DW sebesar 1.975. Nilai ini akan dibandingkan dengan nilai tabel dengan menggunakan nilai signifikansi 5\%, dengan jumlah sampel sebanyak 96 (n) dan jumlah variabel independen $1(\mathrm{k}=1)$ sebagai berikut:

Tabel

Tabel Pengambilan Keputusan Uji Autokorelasi

JIEB, Jilid 6, No 1,19 Maret 2020 ISSN Online 2615-2134 


\begin{tabular}{|l|c|c|}
\hline \multicolumn{1}{|c|}{ Kesimpulan } & Keputusan & Jika \\
\hline Ada autokorelasi & Tolak & Kurang dari \\
Tanpa kesimpulan & No desicision & 1,08 \\
Tidak ada autokorelasi & Tdk Tolak & 1,08 s/d 1,66 \\
Tanpa kesimpulan & No desicision & 1,66 s/d 2,34 \\
Ada korelasi & Ditolak & 2,34 s/d 2,92 \\
& & Lebih dari 2,92 \\
\hline
\end{tabular}

Sumber: Ghozali (2006:96)

Nilai DW 1.975 lebih besar dari batas atas (du) 1.66 dan kurang dari 2,34 (4-du), maka dapat disimpulkan bahwa tidak ada autokorelasi positif atau negatif. Dengan demikian dapat disimpulkan tidak terdapat autokorelasi.

\section{Hasil Analisis Regressi}

Hasil analisis regresi linier berganda dengan program SPSS ver 15 for windows dimaksudkan untuk menganalisis tentang besarnya pengaruh dari variabel manajemen resiko terhadap sistem pemberian kredit yaitu dengan melihat besar koefisien determinasi (R Square). Dalam penelitian ini terdapat 1 (satu) variabel dependent, yaitu daya tarik pariwisata dan 1 (satu) variabel independent yaitu strategi komunikasi pemasaran terpadu. Berdasarkan hal tersebut maka metode analisis yang digunakan adalah simple regression.

Dari analisa regresi yang dilakukan dengan menggunakan bantuan Program SPSS ver 15 for windows, hasil olah data dapat terlihat seperti tabel 4 berikut:

Tabel Analisa Regresi

$\mathrm{N}=96$

\begin{tabular}{|l|l|r|r|r|r|r|}
\hline \multicolumn{2}{|c|}{} & \multicolumn{2}{|c|}{$\begin{array}{c}\text { Unstandardized } \\
\text { Coefficients }\end{array}$} & $\begin{array}{c}\text { Standardized } \\
\text { Coefficients }\end{array}$ & \multirow{2}{*}{ t } & Sig. \\
\cline { 3 - 7 } \multicolumn{2}{|c|}{} & \multicolumn{1}{|c|}{ B } & \multicolumn{1}{c|}{$\begin{array}{c}\text { Std. } \\
\text { Error }\end{array}$} & \multicolumn{1}{c|}{ Beta } & & \\
\hline 1 & (Constant) & 27.351 & 3.176 & & 8.612 & .000 \\
\hline & $\begin{array}{l}\text { Komunikasi.Pemasaran. } \\
\text { Terpadu }\end{array}$ & .657 & .046 & .349 & 3.608 & .000 \\
\hline
\end{tabular}

a Dependent Variable: Daya.Tarik.Pariwisata

Sumber: Data Primer Yang Diolah.

Berdasarkan tabel di atas, maka persamaan regresi yang di dapat adalah sebagai berikut:

$$
\mathrm{Y}=27,351+0,657 \mathrm{X}
$$

Keterangan :

$\mathrm{Y} \quad=$ Daya Tarik Pariwisata

$\mathrm{X}=$ Strategi Komunikasi Pemasaran Terpadu

Persamaan model matematis di atas menunjukkan bahwa strategi komunikasi pemasaran terpadu berpengaruh terhadap daya tarik pariwisata. Hal 
itu ditunjukkan dari koefisien regresi strategi komunikasi pemasaran terpadu yaitu positif 0,657 .

Hasil analisis koefisien korelasi antar variabel independent dapat disajikan dalam tabel berikut:

Tabel Hasil Koefisien Korelasi

$\mathrm{N}=96$

\begin{tabular}{|l|c|c|l|}
\hline $\begin{array}{c}\text { Koefisien } \\
\text { Antara }\end{array}$ & $\begin{array}{c}\text { Koefisien } \\
\text { Kolerasi }\end{array}$ & Sign & Keterangan \\
\hline$X_{1} \leftrightarrow X_{2}$ & 0,783 & 0,000 & Signifikan \\
\hline$X_{2} \leftrightarrow X_{3}$ & 0,740 & 0,000 & Signifikan \\
\hline$X_{3} \leftrightarrow X_{4}$ & 0,713 & 0,000 & Signifikan \\
\hline$X_{1} \leftrightarrow X_{3}$ & 0,632 & 0,000 & Signifikan \\
\hline$X_{1} \leftrightarrow X_{4}$ & 0,520 & 0,000 & Signifikan \\
\hline$X_{2} \leftrightarrow X_{4}$ & 0,606 & 0,000 & Signifikan \\
\hline
\end{tabular}

Sumber: Data Primer Yang Diolah

Berdasarkan tabel di atas dapat ditunjukkan besarnya masing-masing pengaruh dan korelasi pada gambar berikut ini:

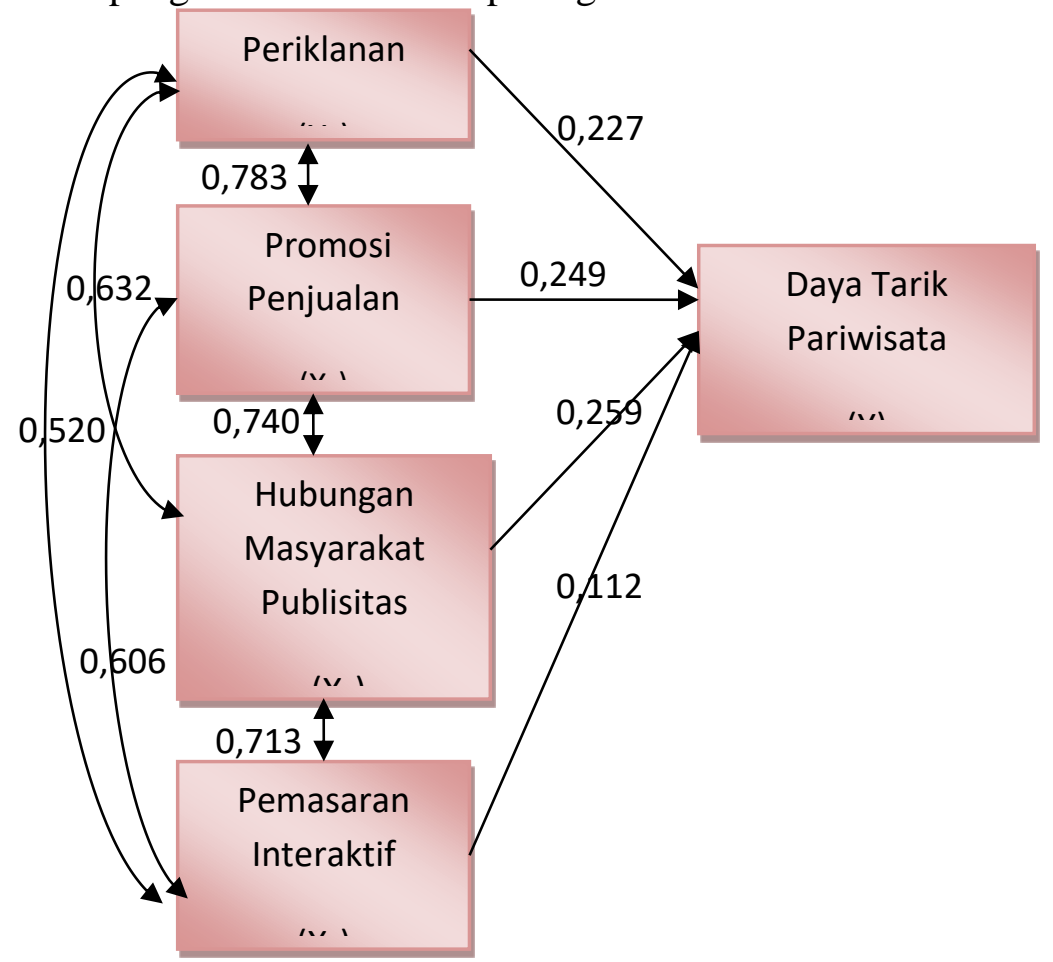

Gambar: Koefesien Path Analysis

Berdasarkan hasil ouput pada gambar di atas dapat, maka dapat dihitung pengarung langsung dan pengarung tidak langsung serta total pengaruh pada tabel berikut:

Tabel Pengaruh Langsung dan Tidak Langsung

$\mathrm{N}=96$ 


\begin{tabular}{|c|c|c|c|c|c|c|c|}
\hline \multirow[b]{2}{*}{ Variabel } & \multirow[b]{2}{*}{$\begin{array}{l}\text { Pengaruh } \\
\text { Langsun } \\
\text { g }\end{array}$} & \multicolumn{4}{|c|}{ Pengaruh Tidak Langsung } & \multirow[b]{2}{*}{$\begin{array}{c}\text { Jumlah } \\
\text { Pengaruh } \\
\text { Tidak } \\
\text { Langsung }\end{array}$} & \multirow[b]{2}{*}{$\begin{array}{l}\text { Total } \\
\text { Pengaru } \\
\text { h }\end{array}$} \\
\hline & & $\begin{array}{c}\text { Periklana } \\
\mathrm{n}\end{array}$ & $\begin{array}{c}\text { Promosi } \\
\text { Penjuala } \\
n\end{array}$ & $\begin{array}{l}\text { Hubungan } \\
\text { Masyaraka } \\
\text { t Publisitas }\end{array}$ & $\begin{array}{c}\text { Pemasara } \\
n \\
\text { Interaktif }\end{array}$ & & \\
\hline Periklanan & $5.2 \%$ & & $4.4 \%$ & $3.7 \%$ & $1.3 \%$ & $9.5 \%$ & $14.6 \%$ \\
\hline $\begin{array}{l}\text { Promosi } \\
\text { Penjualan }\end{array}$ & $6.2 \%$ & $4.4 \%$ & & $4.8 \%$ & $1.7 \%$ & $10.9 \%$ & $17.1 \%$ \\
\hline $\begin{array}{l}\text { Hubungan } \\
\text { Masyaraka } \\
\text { t Publisitas }\end{array}$ & $6.7 \%$ & $3.7 \%$ & $4.8 \%$ & & $2.1 \%$ & $10.6 \%$ & $17.3 \%$ \\
\hline $\begin{array}{l}\text { Pemasaran } \\
\text { Interaktif }\end{array}$ & $1.3 \%$ & $1.3 \%$ & $1.7 \%$ & $2.1 \%$ & & $5.1 \%$ & $6.3 \%$ \\
\hline Total & $19.3 \%$ & & & & & $36.0 \%$ & $55.3 \%$ \\
\hline
\end{tabular}

Sumber: Data Primer Yang Diolah

Adapun pengaruh total pengaruh periklanan, promosi penjualan, hubungan masyarakat publisitas dan pemasaran interaktif terhadap daya tarik pariwisata berikut:

1. Variabel periklanan mempunyai total pengaruh terhadap variabel daya tarik pariwisata sebesar $14,6 \%$.

2. Variabel promosi penjualan mempunyai total pengaruh terhadap variabel daya tarik pariwisata sebesar $17,1 \%$.

3. Variabel hubungan masyarakat publisitas mempunyai total pengaruh terhadap variabel daya tarik pariwisata sebesar $17,3 \%$.

4. Variabel pemasaran interaktif mempunyai total pengaruh terhadap variabel daya tarik pariwisata sebesar 146,3\%.

Adapun besaran pengaruh total (koefisien determinasi) dari variabel periklanan, promosi penjualan, hubungan masyarakat publisitas dan pemasaran interaktif terhadap daya tarik pariwisata, dinyatakan oleh besaran koefisien determinasi yang besarnya adalah $55,3 \%$ sedangkan sisanya $44,7 \%$ dipengaruhi variabel lain diluar model penelitian.

\section{Pengujian Hipotesis}

a. Uji Hipotesis Parsial (Uji-t)

Berdasarkan tabel 4.23 tersebut diatas, dapat dilihat bahwa nilai probabilitas signifikansi atau p value-nya adalah 0.000 atau lebih kecil dari 0.05 atau $5 \%$ dan koefisien regresi-nya adalah positif 0.657 yang artinya hipotesis yang berbunyi strategi komunikasi pemasaran terpadu berpengaruh positif dan signifikan terhadap daya tarik pariwisata di Kota Banjarmasin dapat dibuktikan. Hal ini didukung oleh penelitian yang dilakukan oleh Sutiksno (2010:89) yang menyatakan bahwa komunikasi pemasaran terpadu berpengaruh positif terhadap kepercayaan seseorang untuk berkunjung ke suatu obyek. Artinya advertising memiliki peranan yang cukup besar dalam meningkatkan daya tarik pariwisata. Kondisi ini menggambarkan bahwa advertising telah menarik perhatian wisatawan. Hal ini dapat terlihat dari reaksi wisatawan yang sangat tertarik dengan adanya 
iklan. Karena penyampaian iklan sangat menarik dan telah mempromosikan semua jenis pariwisata dan fasilitas terbaru yang ada melalui media cetak dan elektronik, sehingga frekuensi dan daya jangkau iklan sangat luas di seluruh Indonesia bahkan hingga bisa mencapai ke manca Negara. Hal ini didukung pula oleh Internet marketing (website), dari segi internet marketing melalui website dinilai cukup baik, namun para wisatawan khususnya wisatawan domestik yang berkunjung tidak banyak yang mengetahui adanya website. Oleh karena itu, pihak pengelola pariwisata hendaknya dapat lebih mensosialisasikan website tersebut kepada masyarakat Indonesia, yaitu melalui desain stiker pariwisata juga pada logo pariwisata juga terdapat alamat website pariwisata. Selain itu, pada spanduk dan Billboard yang dipasang di jalan raya juga tercantum website. Pihak pengelola pariwisata hendaknya dapat lebih mempromosikan produknya melalui websitenya. Misalnya, para pengrajin serat alam dapat melakukan penjualan secara online. Bagi wisatawan yang membeli secara online akan mendapatkan potongan harga sejumlah $10 \%$ hingga $20 \%$. Jumlah penduduk Indonesia yang sangat banyak dapat berpotensi sebagai calon wisatawan yang sangat potensial.

b. Uji Hipotesis Simultan (Uji-f)

Hasil uji signifikansi simultan (uji-F) dengan menggunakan Program SPSS ver 15 for windows adalah sebagai berikut:

Tabel Hasil Uji Silmutan (Uji-F)

\begin{tabular}{|l|l|r|r|r|r|l|}
\hline Model & & $\begin{array}{c}\text { Sum of } \\
\text { Squares }\end{array}$ & df & Mean Square & F & Sig. \\
\hline 1 & Regression & 486.265 & 4 & 121.566 & 4.845 & $.001(\mathrm{a})$ \\
\hline & Residual & 2283.391 & 91 & 25.092 & & \\
\hline & Total & 2769.656 & 95 & & & \\
\hline
\end{tabular}

a Predictors: (Constant), Pemasaran.Interaktif, Periklanan,

Hubungan.Masyarakat.Publisitas, Promosi.Penjualan

b Dependent Variable: Daya.Tarik.Pariwisata

Berdasarkan tabel tersebut di atas, dapat ketahui bahwa nilai probabilitas signifikansi atau $p$ value-nya adalah 0,000 yang berarti lebih kecil dari 0.05 atau $5 \%$ dan nilai $\mathrm{f}_{\text {hitung }}$ sebesar 4,845 lebih besar dari nilai $\mathrm{f}_{\text {tabel }}$ sebesar 1,879 dengan demikian komponen komunikasi pemasaran terpadu yang terdiri periklanan, promosi penjualan, hubungan masyarakat dan publisitas serta pemasaran interaktif secara simultan berpengaruh positif dan signifikan terhadap daya tarik pariwisata Kota Banjarmasin. Menurut Sutisna (2002:267) Komunikasi pemasaran merupakan usaha untuk menyampaikan pesan kepada publik terutama konsumen sasaran mengenai keberadaan produk dipasar. Sedangkan menurut Pickton dan Broderick (2001:3) menyatakan, Komunikasi pemasaran merupakan seluruh elemen promosi dari bauran pemasaran yang melibatkan komunikasi antara organisasi dan target audiensnya pada semua permasalahan yang menyangkut kinerja pemasaran. Konsep komunikasi pemasaran ini mengilhami munculnya Komunikasi Pemasaran Terpadu (KPT) atau Integrated Marketing Comunication (IMC). IMC sebagai 
perencanaan konsep komunikasi pemasaran dengan mengidentifikasi nilai tambah rencana komprehensif yang mengevaluasi peran strategis dari ilmu komunikasi yang bervariasi misalnya advertising, sales promotion, direct marketing, public relation, personal selling, internet marketing, dan mengkombinasikan ilmu ini untuk menghasilkan dampak komunikasi yang jelas, konsisten, dan maksimal. Oleh karena itu, usaha mengkomunikasikan produk dan jasa kini dilakukan dengan berbagai pendekatan, tujuannya adalah untuk memenangkan posisi dihati dan keputusan konsumen.

\section{Goodness of Fit Model (Koefisien Determinasi)}

Untuk mengukur seberapa jauh kemampuan variabel bebas dalam menerangkan variabel yang terikat digunakan uji koefisien determinasi dari harga $\mathrm{R}^{2}$. Perhitungan regresi hasil olah data SPSS ditunjukkan pada tabel berikut ini:

Tabel 4 Koefisien Determinasi

\begin{tabular}{|l|c|r|r|c|}
\hline Model & R & R Square & $\begin{array}{c}\text { Adjusted } \\
\text { R Square }\end{array}$ & $\begin{array}{c}\text { Std. Error } \\
\text { of the } \\
\text { Estimate }\end{array}$ \\
\hline 1 & $.649(\mathrm{a})$ & .421 & .401 & 5.08722 \\
\hline
\end{tabular}

a Predictors: (Constant), Komunikasi.Pemasaran.Terpadu

b Dependent Variable: Daya.Tarik.Pariwisata

Berdasarkan tampilan output SPSS model summary, besarnya adjusted $\mathrm{R}^{2}$ adalah 0,421 , hal ini berarti $42,1 \%$ variabel dependen daya tarik pariwisata dapat dijelaskan atau dipengaruhi oleh variabel independent strategi komunikasi pemasaran terpadu, sedangkan sisanya 47,9\% (100\%-42,1\%) dijelaskan oleh sebab-sebab yang lain di luar model ini yang antara lain factor ketersediaan sarana dan prasarana, kebersihan lingkungan, akses jalan dan lain sebagainya. Sarana Pariwisata merupakan fasilitas dan perusahaan yang memberikan pelayanan kepada wisatawan baik secara langsung maupun tidak langsung. Maju mundurnya sarana kepariwisataan tergantung pada jumlah kunjungan wisatawan. Sarana pariwisata meliputi ketersediaan perusahaan perjalanan, perusahaan trasportasi, biro perjalanan dan sebagainya. Sedangkan Prasarana pariwisata adalah semua fasilitas utama atau dasar yang memungkinkan sarana kepariwisataan dapat hidup dan berkembang dalam rangka memberikan pelayanan kepada para wisatawan. Termasuk prasarana pariwisata perhubungan yang meliputi: jalan raya, jembatan dan terminal bus, rel kereta api dan stasiun, bandara (air-port), instalasi listrik dan instalasi air bersih, prasarana kesehatan seperti rumah sakit dan pusat kesehatan masyarakat dan prasarana keamanan, pendidikan dan hiburan.

\section{Kesimpulan dan Saran}

Berdasarkan hasil penelitian menunjukkan bahwa secara umum strategi komunikasi pemasaran terpadu pada produk ekonomi kreatif di Kota Bajarmasin telah dilaksanakan dengan baik. Hal ini terlihat dari maroritas jawaban responden yang menyatakan setuju dengan pertanyaan yang diajukan. Namun dari keempat faktor pembentuk komunikasi pemasaran terpadu, aspek hubungan masyarakat dan 
publisitas serta periklanan merupakan faktor pembentuk yang memiliki peranan paling kuat dan telah dilaksanakan dengan cukup baik. Artinya secara keseluruhan pihak pengelola pariwisata maupun industri pariwisata ekonomi kreatif telah melakukan serangkaian promosi untuk memperkenalkan apa yang dimiliki kepaca seluruh calon wisatawan melalui berbagai media.

Secara umum daya tarik pariwisata Kota Bajarmasin sebagai destinasi pariwisata dari sudut pandang wisatawan cukup baik. Hal ini terlihat dari mayoritas jawaban responden yang menyatakan setuju dengan pertanyaan yang diajukan pada kuesioner daya tarik pariwisata. Artinya wisatawan mempersepsikan positif pariwisata yang ditawarkan, hal ini tidak terlepas dari peran serta berbagai pihak yang memfasilitas dan mendukung pengembangan sektor pariwisata Kota Bajarmasin khususnya dibidang industri ekonomi kreatif.

\section{DAFTAR USTAKA}

Algifari. 2002. Analisis Regresi:Teori, Kasus dan Solusi, Yogyakarta:Liberty.

Alvin Toffler. 2000. Pembagian Gelombang Peradaban Ekonomi. Alih Bahasa Ardian Hakim. Bandung: CV. Alfabeta.

Arikunto, Suharsimi. 2005. Prosedur Penelitian Suatu Pendekatan Praktek. Jakarta: PT. Rineka Cipta.

Cooper \& Schindler. 2007. Marketing Research. New York: The McGraw-Hill Companies, Inc.

Dos Santos. 2007. The Creative Economy. New Jersey. Prentice Hall.

E. Maryani. 1991. Pengantar Geografi Pariwisata. Jurusan Pendidikan Geografi FPIPS IKIP Bandung.

Ghozali, Imam, 2005. Aplikasi Analisis Multivariate dengan Program SPSS, Edisi. Ketiga, Badan Penerbit Universitas Diponegoro, Semarang.

Ghozali, Imam. 2001. Aplikasi Analisis Multivariate dengan Program SPSS. Semarang: Badan Penerbit Universitas Diponegoro.

Gunawan, Adisaputra dan Marwan Asri. 2003. Anggaran Perusahaan. Yogyakarta: BPFE Universitas Gajah Mada.

Hasyim, A. 2010. Komunikasi Pemasaran Terpadu dalam Bidang Jasa. Jakarta : Bumi Aksara.

Howkins. 2001. Consumer Behavior: Building Marketing Strategy. New York: York McGraw Hill.

Kotler, P., \& Armstrong, G. 2002. Prinsip-prinsip pemasaran (12ed.). Jakarta: Penerbit Erlangga.

Kotler, Philip dan Keller, Kevin Lane. 2001. Marketing Management. New Jersey: Pearson Education International.

Kotler, Philip, 2004, Manajemen Pemasaran, Edisi Millenium, Penerbit PT. Jakarta: Prenhallinda.

Mahakami, Eka Tamia. 2008. Pengaruh Faktor Komunikasi Pemasaran Perusahaan terhadap Keputusan Pembelian Konsumen (Studi Kasus pada Wisatawan Domestik di Taman Safari Indonesia, Cisarua, . Bogor). Bogor: Program Studi Menejemen Fakultas Ekonomi dan Menejemen. Institut Pertanian Bogor. 
Morissan, 2010. Periklanan Komunikasi Pemasaran Terpadu. Jakarta: Kencana Prenada Media Group.

Morissan, Alexander. 2007. Periklanan Komunikasi Pemasaran Terpadu. Jakarta: Ramdina Prakarsa.

Morissan. 2006. Pengantar Public Relations-Strategi Menjadi Humas. Profesional, Tanggerang: Penerbit Ramdina Prakasa.

Nazir. 2005, Metode Penelitian. Ghalia Indonesia. Bogor.

Pawitra, Teddy, 2001, Perilaku Konsumen dan Komunikasi Pemasaran,. PT. Remaja Rosdakarya, Bandung.

Pendit, S Nyoman. (1995). Ilmu Pariwisata Sebuah Pengantar Perdana. Jakarta: PT. Pradnya Paramitagt.

Pickton, D., \& Broderick, A. 2001. Integrated Marketing Communication. Prentice Hall, London.

Pritasani, Aurora Kamarga, 2012, "Pengaplikasian Integrated Marketing Communication pada Peningkatan Penjualan Ekspor Perusahaan Manufaktur", Jurnal Ekonomika, Vol. 5 No. 2.

Romer, Paul. 2003. "Looting: The Economic Underworld of Bankruptcy for rofit" with George Akerlof (Brookings Papers on Economic Activity 2, William C. Brainard and George L. Perry (eds.), , pp. 1-74).

Rusmini, 2013, "Strategi Promosis sebagai Dasar Peningkatan Respons Konsumen”, Jurnal Pengembangan Humaniora, Vol. 13, No. 1.

Sedarmayanti. 2002. Metodologi Penelitian. Bandung: Mandar. Maju.

Sekaran, Uma, 2003, Research Methods for Business: A Skill Building Approach.

New York: John Willey \& Sons.

Sugiyono, 2002, Metode Penelitian Kuantitatif, Kualitatif dan R \& D, Bandung: CV Alfabeta.

Sugiyono, 2006, Statistika Untuk Penelitian, Cetakan Ketujuh, Bandung: CV. Alfabeta.

Sugiyono. 2004, Metode Penelitian Bisnis, Bandung: CV Alfabeta.

Susan, Dewi. 2004. Strategi Pengembangan Ekonomi Kreatif. Bandung: Angkasa.

Sutiksno. 2010. Analisis Pengaruh Komunikasi Pemasaran Terpadu terhadap Tingkat Kepercayaan pada Obyek Wisata. Journal Pariwisata, Vol. 7, No. 13, pp 22-39.

Sutisna. 2002. Perilaku Konsumen dan Komunikasi Pemasaran. Bandung: PT Remaja. Rosdakarya.

Suziana. 2005. Analisis Pengaruh Promosi Penjualan terhadap Sikap Konsumen. Jurnal Pemasaran, Vol 04, No. 7, pp. 12-36.

Yoeti, A Oka. 1996. Pemasaran Pariwisata. Jakarta : PT Pradnya Paramita.

Yoeti, A Oka. 2000. Tours and Travel. Jakarta : PT Pradnya Paramita.

Yoeti, A Oka. 2002. Perencanaan dan Pengembangan Pariwisata. Jakarta :PT Pradnya Paramita. 